Poyer, Robert K. "Improved Library Services Through User Education," Bulletin of the Medical Library Association 65(April 1977):296-97.
White, Donald J. "Orientation Course Aids Staff on the Job." Canadian Library Journal 36(February/April 1979):17-20.

\title{
ACRL continuing education courses at Midwinter Conference
}

The Association of College and Research Libraries will sponsor four continuing education courses at the ALA Midwinter Meeting in Washington, D.C. Advance registration by December 15 is required. A late registration fee of $\$ 15$ will be charged.

A Certificate of Completion will be awarded participants in each course. Successful completion of 10 contact hours of continuing education is equal to one Continuing Education Unit (CEU). ACRL maintains a CEU record for each participant.

To register, send in a completed registration form to Gail Russell, ACRL/ALA, 50 E. Huron Street, Chicago, IL 60611-2795. Details of the courses follow:

\section{Job Training: Developing Training Plans FOR YOUR STAFF}

CE 110 explains why initial orientation and training is critical to effective operation of library departments. The course covers: areas requiring training (for the new employee, for performance improvement, in operational problems or changes and for development of the employee) and the responsibility of the supervisor in planning, conducting and evaluating training. The course reviews learning principles. Participants will work on developing a training plan and/or materials for their own employees and will practice giving feedback - both criticism and praise-to their trainees. Evaluating the effectiveness of the training program will also be covered.

Instructor: Anne Lipow, Director of Library Education, University of California, Berkeley.

Date: Friday, January 4, 1985, 9:00 a.m.-5:00 p.m.

Fee: $\$ 95$ ACRL members; $\$ 135$ non-members. CEU credit: .7

What past participants have said about CE 110: "Excellent course." "Lots of good practical ideas to

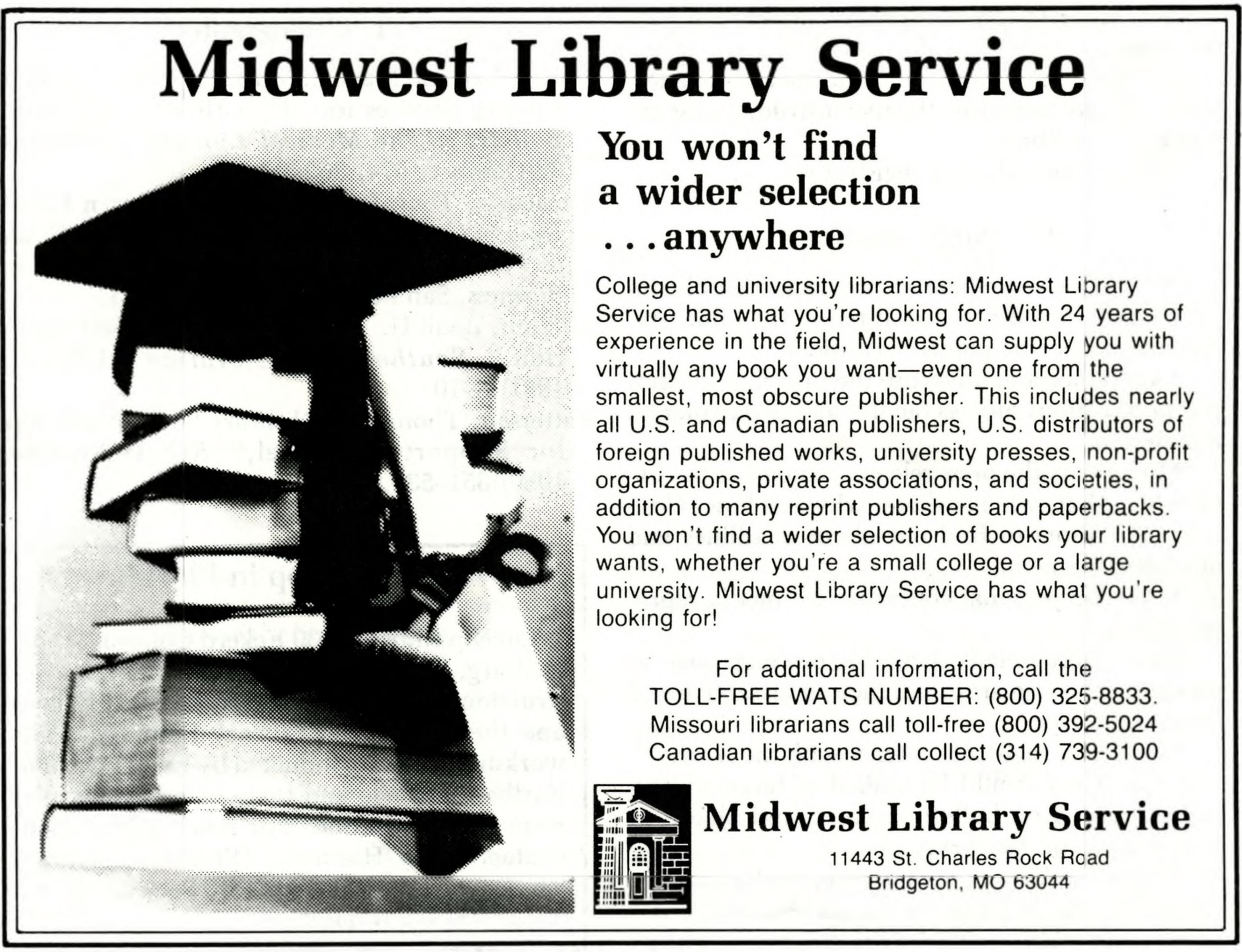




\section{REGISTRATION FORM \\ CONTINUING EDUCATION COURSES}

\section{PLEASE PRINT}

NAME

AFFILIATION

STREET

(indicate home or work)

CITY

STATE

ZIP

DAYTIME PHONE

ALA/ACRL MEMBERSHIP \#

PLEASE CIRCLE THE APPROPRIATE DOLLAR AMOUNT FOR THE COURSE OF YOUR CHOICE, AND INDICATE YOUR PREFERENCES IN THE MARGIN (1st, 2nd, and 3rd).

Course

ACRL Member Non-member

CE 110 Job Training: Developing Training Plans for Your Staff (January 4)

$\$ 95 \quad \$ 135$

CE 112 Improving Job Performance: Strategies for Supervisors (January 4)

CE 205 Teaching How to Teach Science Reference Materials

$\$ 140$

$\$ 200$ (January 3-4)

CE 501 Writing the Journal Article and Getting It Published (January 4)

${ }^{*}$ Late registration fee

$\$ 15$

$\$ 15$

\section{ENTER TOTAL AMOUNT ENCLOSED}

${ }^{*}$ Fee for registration after December 15 .

CONFIRMATION: Written confirmations will be made.

CANCELLATIONS: Written notice of cancellations received by December 15 will be honored subject to a $\$ 20$ cancellation charge. No refunds for cancellations after December 15.

You may make checks payable to ACRL and return them with this form to:

\section{ACRL-Continuing Education \\ American Library Association \\ 50 E. Huron St. \\ Chicago, IL 60611}

In order to help $\mathrm{CE}$ instructors prepare for their courses, please answer the following questions:

1. What do you hope to gain by taking this course?

2. What experience or education have you had in this area prior to enrollment in this CE course?

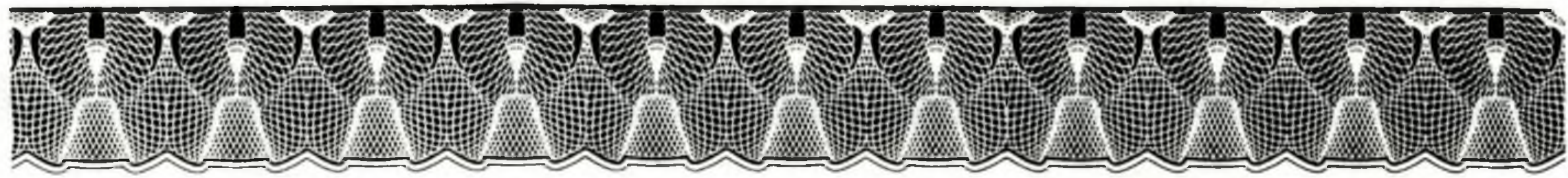




\section{The why, wherefore, $\&$}

Research for Decision Making: Methods for Librarians, by Robert Swisher and Charles R. McClure.

How to do action research - research central to clarifying and supporting library decision making. $\$ 25.00 \mathrm{cl} \quad$ xvi, 212p. $0-8389-0398-3$ 84-12381 Sept. 1984
National Planning for Library Service, 1935-1975, by R. Kathleen Moly.

This analysis of why planning evolved as it did shows today's planners how to approach similar library and related public policy issues.

\$15.00pbk 112p. $0-8389-0422-\mathrm{X}$ 84-18407 Dec. 1984

\section{bow-to in}

New Library and Information

Technology Series

Crossroads: Proceedings of the First

National Conference of the Library and Information Technology Association, September 1983,

edited by Michael Gorman.

tl research and progress reports detailing the wherefores of current library and information technology. No. 1 in the series. $\$ 40.00$ pbk x, 262p. 0-8389-3307-6 8+-10965 Oct. 1984

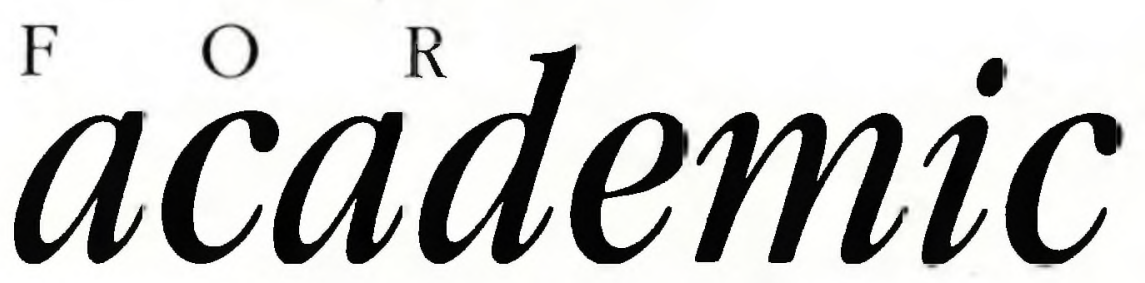

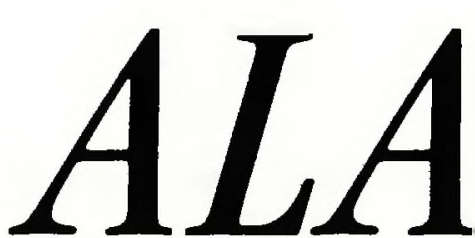

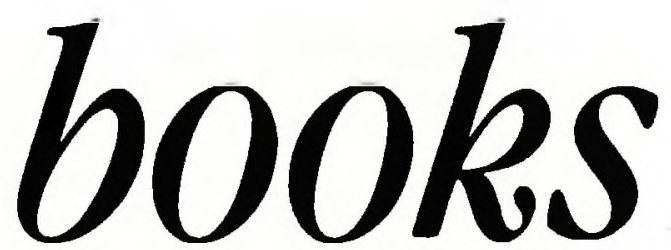

Online Catalogs, Online Reference: Converging Trends, edited by Brian Aveney and Brett Butler.

Proceedings of a LITA preconference institute telling how the parallel developments of online catalogs and reference may merge. No. 2 in the series.

$\begin{array}{ll}\$ 20.00 \text { pbk } & \text { vi, 212p. } \quad 0-8389-3308-4 \\ 84-11023 & \text { Oct. } 1984\end{array}$

librarians

Acquisitions Management and Collection Development in Libraries, by Rose Mary Magrill and Doralyn J. Hickey.

How to manage an acquisitions program and how to plan, develop, and evaluate collections.

$\$ 20.00 \mathrm{cl}$ xi, 229p. $0-8389-0408-4$

84-9288 Sept. 1984
American Library Association

Publishing Services

50 East Huron Street

Chicago, Illinois 60611 
take home!"

Improving Job Performance:

Strategies FOR SUPERVISORS

CE 112 will help librarian-supervisors: create a climate for motivation, define job competencies, set performance standards, address performance problems and improve work effectiveness of their staffs. This course is intended for librarians who are first-line supervisors or middle managers. Past participants to CE 101 note: the material presented in this course will build upon the knowledge and skills developed in ACRL CE 101, Librarians as Supervisors.

Instructor: Maureen Sullivan, Head of Personnel, Yale University Library.

Date: Friday, January 4, 1985, 9:00 a.m.-5:00 p.m.

Fee: $\$ 95$ ACRL members; $\$ 135$ non-members.

CEU credit: .7

What past participants have said about CE 112: "Unusually good presentation from all points of view. Impressive." "Ms. Sullivan offered excellent ideas, controlled topics well, presented material well."

Teaching How to Teach Science Reference Materials: A Workshop for Librarians Who SERVE THE UNDERGRADUATE

CE 205 examines the search strategies and reference tools (especially such science periodical indexes as the H.W. Wilson indexes, Biological Abstracts, Chemical Abstracts, and Science Citation Index) that are particularly useful to undergraduate science majors. Equal emphasis is given to methods of teaching these search strategies and the use of these reference tools. Methods of learning how to use new science reference materials are also covered.

Instructor: Thomas Kirk, College Librarian, Berea College. Mr. Kirk is the recipient of the 1984 ACRL Miriam Dudley Bibliographic Instruction Librarian of the Year Award.

Date: Thursday, January 3, 1:30-5:00 p.m.; Friday, January 4, 9:00 a.m.-5:00 p.m.

Fee: \$140 ACRL members; \$200 non-members. CEU credit: 1.1

What past participants have said about CE 205: "Good syllabus, instructor knowledgeable. Good

\section{Lest you forget}

December 1, 1984, is the deadline for nominations for the ACRL Academic or Research Librarian of the Year Award and for applications for the ACRL/ISI fellowships for 1985. Information on both may be found in $C \& R L$ News, September 1984, pp. 394-95, 421. Contact Sandy Whiteley, ACRL/ALA, $50 \mathrm{E}$. Huron St., Chicago, IL 60611; (312) 944-6780. opportunity for interaction." "The manual and material presented were most effective in showing problems and means for improving teaching the undergraduate science tools."

\section{Writing the Journal Article and Getting It Published}

CE 501 provides participants with an overview of the publishing process and helps them devise an effective strategy for publishing their work. Topics will include selection of a publishing medium, preparation of the manuscript, submission of the manuscript, and pre- and post-publication matters.

Instructor: Richard D. Johnson, Director of Libraries, State University College, Oneonta, New York. Mr. Johnson is the recipient of the 1984 ACRL Academic or Research Librarian of the Year Award.

Date: Friday, January 4, 9:00 a.m.-5:00 p.m.

Fee: $\$ 95$ ACRL members; $\$ 135$ non-members.

CEU credit: .7

What past participants have said about CE 501: "An excellent and very enjoyable presentation, full of practical help with concern and support of colleagues paramount. Atmosphere open, relaxed and lively." "I am well satisfied. The preparation and presentation show keen interest in helping us to achieve goals."

\section{First IAIMS grants awarded}

As a result of a new grant initiative announced in August 1983 (see C $d R L$ News, October 1983, p.353), the first National Library of Medicine Medical Library Resource Project Grant awards supporting strategic planning for Integrated Academic Information Management Systems (IAIMS) have been issued.

The awardees are the University of Cincinnati Medical Center, Nancy M. Lorenzi, principal investigator, a grant of $\$ 161,251$; and Baylor College of Medicine, Houston, G. Anthony Gorry, principal investigator, a grant of $\$ 178,425$.

These institutions will begin the process of planning the management of health science knowledge by incorporating information and computer technologies to develop integrated information system models for their facilities.

The IAIMS concept was first proposed in a report from the Association of American Medical Colleges entitled, "Academic Information in the Academic Health Sciences Center: Roles for the Library in Information Management" (Part 2, Journal of Medical Education, October 1982). Instructions, application forms, and additional information may be obtained from the IAIMS Program Officer, Extramural Programs, National Library of Medicine, Bethesda, MD 20209; (301) 496-3113. 